\title{
Occurrence, Diversity and Abundance of Nematode Pests of Pineapple (Ananas comosus) in Two Local Government Areas of Rivers State, Nigeria
}

\author{
*TANIMOLA, AA; OLOTU, O; ASIMIEA, AO
}

\author{
Department of Crop and Soil Science, Faculty of Agriculture, University of Port Harcourt, Choba, Rivers State, Nigeria \\ *Corresponding Author Email: tanimoladebo@yahoo.com; Other Authors'Email: shezzman@gmail.com; amina.asimiea@uniport.edu.ng
}

\begin{abstract}
Plant-parasitic nematodes (PPNs) contribute to yield losses in pineapple production. Limited studies have been conducted on plant-parasitic nematodes on pineapple despite reports of PPNs infecting it. A survey was conducted in Obio-Akpor and Ikwerre Local Government Areas (LGAs) of Rivers State to determine the occurrence, abundance and diversity of PPNs associated with pineapple. A total of 60 composite samples were collected from the two LGAs. Nematodes were extracted from soil and root samples using the modified Baermann technique and identified using standard procedures. Data were processed using relative frequency of occurrence (RFOC), relative importance values (RIVs), diversity indices, nematode population was calculated and analysis of variance. The most occurring plant-parasitic nematodes were Pratylenchus, Helicotylenchus, Meloidogyne, Scutellonema and Tylenchulus. In Obio Akpor LGA, Helicotylenchus with RFOC $33.3 \%$ was the most occurring nematode pests, while Pratylenchus was the most important plant-parasitic nematode (RIV 33.8\%). In Ikwerre LGA, both Helicotylenchus and Pratylenchus have the same occurrence (RFOC $33.3 \%$ ) with Pratylenchus being the most important nematode pest. Pratylenchus species with RIV of 52.4\% were the most important PPNs associated with pineapple in both Obio-Akpor and Ikwerre LGAs. Dominance and ShannonWeiner indices among the PPNs are 0.58 and 0.86 , respectively. In Ikwerre and Obio-Akpor LGAs, Aluu (1530) and Rumuekini (630) pineapple farms have the highest population of PPNs, respectively. Ikwerre LGA $(2,150)$ pineapple farms had more PPNs than Obio-Akpor LGA (660). Nematode pests are associated with pineapple in the two LGAs and could be contributing to yield losses.
\end{abstract}

\section{DOI: https://dx.doi.org/10.4314/jasem.v25i4.29}

Copyright: Copyright $\left({ }_{0} 2021\right.$ Tanimola et al. This is an open access article distributed under the Creative Commons Attribution License (CCL), which permits unrestricted use, distribution, and reproduction in any medium, provided the original work is properly cited.

Dates: Received: 20 March 2021; Revised: 21 April 2021; Accepted: 28 April 2021

Keywords: Diversity indices, Extraction, Identification, Occurrence, Plant-parasitic nematodes, Pratylenchus,

Pineapple (Ananas comosus) is a fruit of high value since its introduction from the Caribbean, Oceania and America (de Carvalho, 2020). It is usually eaten fresh or processed into fruit juices and ranks third after banana and citrus, thus contributing over $23 \%$ of the global production of tropical fruits (Kormelinck and Janssen, 2012). Pineapple production is concentrated in the tropical regions of the world in over 82 countries (Ndungu, 2014). The main pineapple producers in the world in 2019 are Costa Rica (3.32 million tonnes), Philippines (2.74 million tonnes), Brazil (2.42 million tonnes), Indonesia (2.19 million tonnes) and China (1.72 million tonnes) (FAOSTAT, 2021). Other important producers of pineapples are India (1.71 million tonnes), Thailand (1.68 million tonnes), Nigeria (1.671 million tonnes), Mexico (1.04 million tonnes) and Columbia (1.01 million tonnes) (FAOSTAT, 2021). Nigeria is the leading producer of pineapple in Africa as well as the eighth major producer in the world in the year 2019 (FAOSTAT, 2021). Nigeria on a land area of about 10,000 hectares (ha) produces yield of 7,778 tonnes/ha of pineapple (FAOSTAT, 2012). This crop is grown more in the Southern and Western parts of the country (Ucheagwu, 1985). The pineapple production in Nigeria is an important means of livelihood for most farmers and it improves quality of rural life in addition to its significant role in the nutrition and health of households. Pineapple fibre has been processed into paper with remarkable qualities of thinness, smoothness and pliability (Montinola, 1991). Parts of the plant are used for silage and hay for cattle feed. Alcoholic beverages can also be made from the juice of this crop. The pineapple juice also has medicinal values such as a diuretic, worm expellant, treatment of venereal diseases and also to expedite labour in women (Morton, 1987). Despite the vast land under pineapple cultivation, there are low yields when compared with production from other countries (Asopa, 2003). Pineapple production in Rivers State and other parts of Nigeria is still on decline despite Nigeria's position and potential in pineapple production and the enormous economic advantages the country has (Mark, 2010). The production is still inadequate to meet the country's demand. Pineapple suffers from a wide range of pests and pathogens that directly or indirectly reduces its yield in quality and quantity (Daramola et al., 2013). Notable among these pests and pathogens are insects, viruses, bacteria, fungi and plant-parasitic nematodes (PPNs) (Sipes, 2000; Daramola et al., 2013). Globally, nematode pests have been implicated in significant yield losses in pineapple (Caswell et al., 1990; Sipes, 2000, USDA, 2003). Caveness (1965), Babatola (1985) and Daramola et al. (2013) reported plant-parasitic nematodes as one of the banes to pineapple production in Nigeria. The 
information garnered on the effect of PPNs on pineapple is still not adequate for they vary in types and populations over time and space (Nicol, 2002). Little is known about the plant-parasitic nematodes associated with pineapple in most Niger Delta States of Nigeria. Information on important agronomic practices for pineapple production exists, but the types and impact of plant-parasitic nematodes on pineapple production in Rivers State is scarce. This study was carried out to provide recent information on plantparasitic nematodes associated with pineapple in two LGAs in Rivers State.

\section{MATERIALS AND METHODS}

Description of the study area: This study was carried out in two Local Government Areas (LGAs), ObioApkor and Ikwerre in Rivers State, Nigeria. Rivers States lies between Latitude 4 ' ' $30^{\circ} \mathrm{N}$ and $5^{\prime}$ ' $45^{\circ} \mathrm{N}$ and longitude $6 " 30^{\circ} \mathrm{E}$ of the Greenwich meridian with a total area of $11,077 \mathrm{~km}^{2}$, mean annual rainfall which ranges from $4,700 \mathrm{~mm}$ on the coast to about $1,700 \mathrm{~mm}$ inland. The State occupies lowland area of Niger Delta with dense and thick tropical rainforest vegetation. It is characterized by high atmospheric (ambient) temperature that ranges between $25^{\circ} \mathrm{C}$ to $38^{\circ} \mathrm{C}$.

Collection of Soil and Root Samples: Soil and root samples were collected using multistage random sampling method. In Obio-Akpor LGA, three pineapple farm communities, Choba, Alakahia and Rumuekini were randomly selected, whereas Aluu, Igwuruta and Omagwa were chosen for Ikwerre LGA (Figure 1). Five Pineapple monoculture farms per community were randomly chosen for collection of roots and soil samples. In a farm, soil samples were randomly collected from the rhizospheres of 10 pineapple stands with hand trowel and then bulked in a well labelled polythene bag. Tender roots were collected around the selected pineapple plants and then bulked, then placed in the same well labelled polythene bag with soil. Five bulked samples of soil and root samples were collected from the five farms in each community and fifteen bulked samples per LGA. A total of thirty (30) bulked samples of both the roots and soil were collected for the two LGAs. A total of 60 samples of roots and soil were collected across pineapple farms in the two LGAs when the samples were separated in the laboratory.

Extraction, Identification and Quantification of Plantparasitic Nematodes: Plant-parasitic nematodes were extracted using pie-pan method (Whitehead and Hemming, 1965). $200 \mathrm{~cm}^{3}$ of sieved soil sample was taken with beaker and poured on a facial tissue in a plastic sieve followed by the addition of water to the extraction plate by the side. Also, the roots of the pineapple were chopped into 1-2 cm length using knife per sample. The chopped roots were thoroughly mixed and $10 \mathrm{~g}$ soil was weighed using electronic balance (Startfrit model 93016; d=1g). The $10 \mathrm{~g}$ soil was later poured into the facial tissue in another plastic sieve and then water added to the extraction plate by the side.

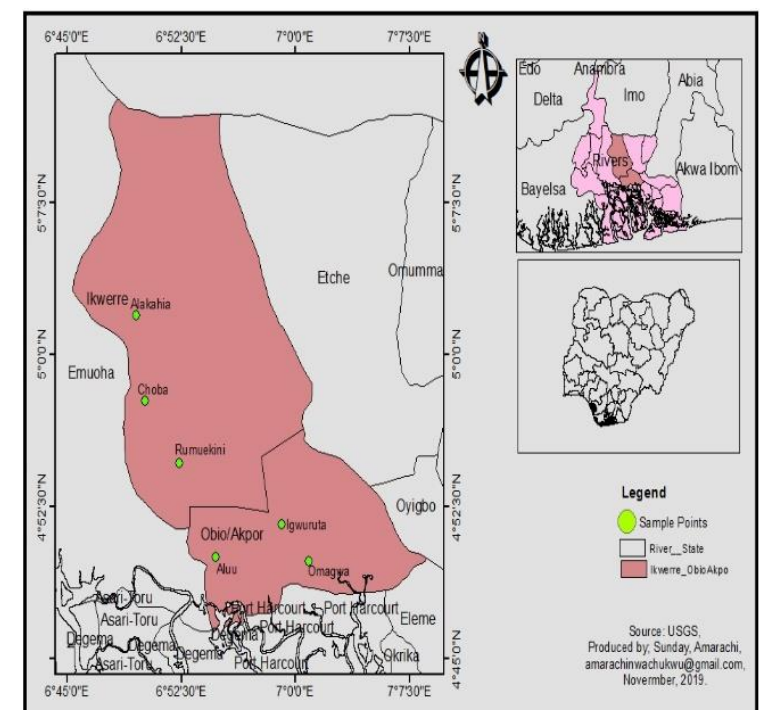

Fig 1: Map showing farm communities where samples were collected in Obio-Akpor and Ikwerre Local Government Areas

The set-up was left for 48 hours for both soil and root extraction plates after which the sieves were later removed. The nematode water suspension in the plate was poured into a beaker and allowed to settle down. After settling, the nematode water suspension was decanted into a sample bottle. Plant-parasitic nematodes were identified using the method described by Dropkin et al. (1960). The concentrated suspension of water and the nematodes from soil and roots were preserved by $4 \%$ of formaldehyde pending identification and counting. Aliquot of $2 \mathrm{ml}$ suspension was pipette into counting slide. The counting slide was placed under a dissecting microscope and compound microscope synchronously for identification and counted using Bell's key (Bell, 2004). Multiple tally counters were used in the counting of the nematodes.

Data Processing and Analyses: Descriptive statistics were used to process data on relative frequency of occurrence using the formula of Norton (1978); relative importance value of plant-parasitic nematode species was determined using the methods of Shukla and Chandel (2014) and Kent and Coker (1996) with modifications. The diversity of nematode communities was determined using the Paleontological Statistical Tool (PAST) of Hammer et al. (2001). Some indices calculated were: Genera (G) or Species Richness (S); Shannon-Wiener index $\left(\mathrm{H}^{\prime}\right):\left(\mathrm{H}^{\prime}\right)=-\sum$ (pi) (Inpi); Evenness index $(J)=H^{\prime} / I n S ;$ Dominance index: Dominance index $=\sum\left(\mathrm{n}_{\mathrm{i}} / \mathrm{n}\right)^{2}$

Data from nematode counts were transformed using $\log 10(\mathrm{x}+1)$, then analyzed with analysis of variance (ANOVA) and means were separated using Fisher's Least Significant Difference at probability of 5\% with Statistical Analysis System (SAS, 2007) package. The 
means of the back-transformed data were presented in the results section

\section{RESULTS AND DISCUSSION}

Helicotylenchus was the most frequently occurring nematode pest in Obio-Akpor Local Government Area (LGA) with the highest relative frequency of occurrence (RFOC) of $33.33 \%$ among the five nematode pest genera found in both soil and roots of pineapple (Table 1). The least frequently occurring nematode genera were Scutellonema and Paratylenchus with RFOC of $11.11 \%$. However, Pratylenchus species with relative importance value (RIV) of $33.83 \%$ was the most important nematode pest associated with pineapple in Obio-Akpor LGA. Scutellonema had the least RIV of $11.61 \%$ among the five nematode pest genera on pineapple (Table 1). In Ikwerre LGA, Pratylenchus and Helicotylenchus with the same RFOC $(33.33 \%)$ were the most frequently occurring nematode pests, whereas Meloidogyne was the least. Pratylenchus with RIV of $58.52 \%$ was the most important nematode pest of pineapple in Ikwerre
LGA, then followed by Helicotylenchus (RIV $20.62 \%$ ). The least important nematode genus was Meloidogyne (2.84\%). Figure 2 shows the diversity indices of plant-parasitic nematodes of pineapple in Obio-Akpor and Ikwerre LGAs. In Obio-Akpor, 220 nematode individuals were encountered which were lower than 716.6 nematode individuals encountered in Ikwerre LGA. Plant-parasitic nematodes associated with pineapple in Obio-Akpor LGA had dominance value of 0.32 compared with 0.71 obtained in Ikwerre LGA. In terms of Simpson diversity index, nematode pest genera in Obio-Akpor LGA had a value of 0.67 , but a lower value of 0.28 in Ikwerre LGA. The Shannon-Wiener index for nematode pests of pineapple in Obio-Akpor LGA was 1.31 this was higher than a value of 0.58 in Ikwerre LGA. The evenness index for plant-parasitic nematodes in ObioAkpor was 0.74 while that of Ikwerre was 0.45 (Figure 2). In Aluu pineapple farms of Ikwerre LGA, Helicotylenchus species with mean population of 120 were the highest, but not significantly higher than the population in Omagwa (Table 3).

Table 1: Occurrence and importance values of plant-parasitic nematodes associated with pineapple in Obio-Akpor and Ikwerre Local Government Areas, Rivers State

\begin{tabular}{|c|c|c|c|c|c|}
\hline \multirow[t]{2}{*}{$\begin{array}{l}\text { Nematode } \\
\text { genera }\end{array}$} & \multirow[t]{2}{*}{ Family } & \multicolumn{2}{|c|}{$\begin{array}{l}\begin{array}{l}\text { Relative frequency } \\
\text { occurrence }(\%)\end{array} \\
\end{array}$} & \multicolumn{2}{|c|}{$\begin{array}{l}\text { Relative importance value } \\
(\%)\end{array}$} \\
\hline & & $\begin{array}{l}\text { Obio-Akpor } \\
\text { LGA }\end{array}$ & $\begin{array}{l}\text { Ikwerre } \\
\text { LGA }\end{array}$ & $\begin{array}{l}\text { Obio-Akpor } \\
\text { LGA }\end{array}$ & Ikwerre LGA \\
\hline Helicotylenchus & Hoplolaimidae & 33.3 & 33.33 & 20.45 & 20.62 \\
\hline Pratylenchus & Pratylenchidae & 22.22 & 33.33 & 33.83 & 58.52 \\
\hline Paratylenchus & Tylenchidae & 11.11 & 28.57 & 20.70 & 18.00 \\
\hline Meloidogyne & Meloidogynidae & 0 & 4.76 & 0 & 2.84 \\
\hline Scutellonema & Hoplolaimidae & 11.11 & 0 & 11.61 & 0 \\
\hline Tylenchus & Tylenchidae & 22.22 & 0 & 13.38 & 0 \\
\hline
\end{tabular}

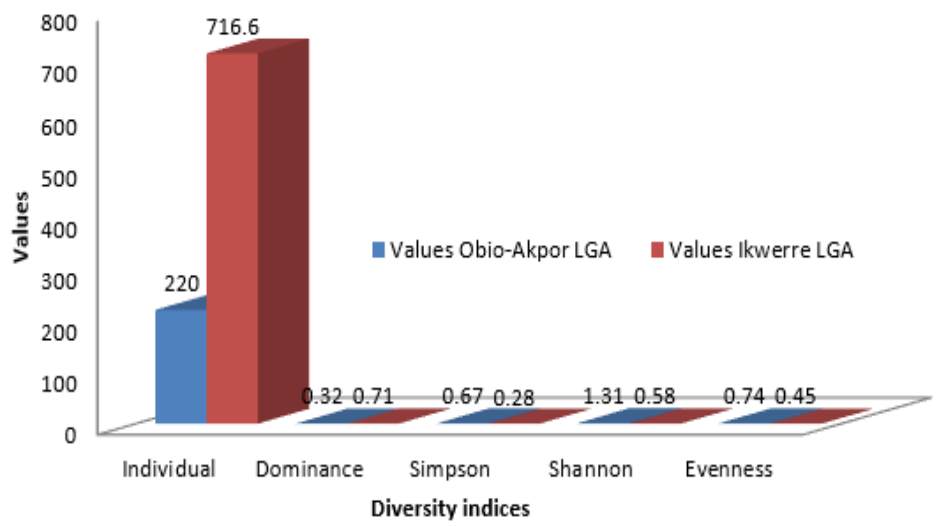

Fig 2: Diversity indices of plant-parasitic nematodes associated with pineapple in Obio-Akpor and Ikwerre Local Government Areas

Similar trend was observed for Pratylenchus and Paratylenchus (Table 3). There was no significant difference in the mean population of Meloidogyne obtained in Omagwa, Aluu and Igwuruta pineapple farms. Aluu pineapple farms had the highest mean population of nematode pests associated with pineapple among the three farm communities and this was significantly higher than those of Omagwa and Igwuruta (Table 3). In Obio-Akpor LGA, Helicotylenchus species had significantly the highest population in Rumuekini than in Choba and Alakahia.
Pratylenchus ranks highest in population among the plant-parasitic nematode genera associated with pineapple in Rumuekini of Obio-Akpor LGA. This population of Pratylenchus in Rumuekini was significantly higher than those of Choba and Alakahia (Table 3). Rumuekini pineapple farm community still had higher population of Paratylenchus (200) and Scutellonema (80) that was not significantly higher than the same species in Choba and Alakahia. Tylenchulus species with a mean population of 30 in Alakahia was not significantly higher in population 
than those at Choba and Rumuekini. Rumuekini pineapple farms recorded the highest mean plantparasitic nematodes which was significantly higher than plant-parasitic nematodes in Choba and Alakahia (Table 3). Figure 3 reveals the occurrence and importance values of plant-parasitic nematodes associated with pineapple across Obio-Akpor and Ikwerre LGAs. Helicotylenchus is the most frequently occurring nematode pest genera (RFOC $33.33 \%$ ), then
Pratylenchus (RFOC 30.0\%) across the six farm locations. In this table, Pratylenchus species has a relative importance value of $52.36 \%$ and this shows that Pratylenchus is the most important nematode pest associated with pineapple across the six farm locations. The least frequently occurring nematode genera were Scutellonema (3.33) and Meloidogyne (3.33). However, Scutellonema had the least RIV of $2.07 \%$ (Figure 3).

\begin{tabular}{|c|c|c|c|c|c|c|c|}
\hline \multirow{2}{*}{$\begin{array}{l}\text { Local } \\
\text { Government } \\
\text { Area/Farm } \\
\text { Locations } \\
\end{array}$} & \multicolumn{6}{|c|}{$\begin{aligned} \text { Plant-parasitic nematode genera } \\
\end{aligned}$} & \multirow{2}{*}{$\begin{array}{l}\text { Total plant } \\
\text { parasitic } \\
\text { nematodes }\end{array}$} \\
\hline & Helicotylenchus & Pratylenchus & Paratylenchus & Meloidogyne & Scutellonema & Tylenchulus & \\
\hline \multicolumn{8}{|l|}{ Ikwerre } \\
\hline Aluu & 120 & 1300 & 110 & 0 & 0 & 0 & 1530 \\
\hline Omagwa & 40 & 400 & 50 & 20 & 0 & 0 & 510 \\
\hline Igwuruta & 10 & 100 & 0 & 0 & 0 & 0 & 110 \\
\hline $\mathrm{LSD}(\mathrm{P} \leq 0.05)$ & 106.74 & 1029.7 & 86.24 & 35.58 & 0 & 0 & 1195.2 \\
\hline \multicolumn{8}{|l|}{ Obio-Akpor } \\
\hline Rumuekini & 50 & 300 & 200 & 0 & 80 & 0 & 630 \\
\hline Choba & 0 & 0 & 0 & 0 & 0 & 0 & 0 \\
\hline Alakahia & 0 & 0 & 0 & 0 & 0 & 30 & 30 \\
\hline $\operatorname{LSD}(\mathrm{P} \leq 0.05)$ & 39.77 & 355.8 & 352.4 & 0 & 142.32 & 35.58 & 425.85 \\
\hline
\end{tabular}

Figure 4 reveals the diversity of plant-parasitic nematode pests associated with pineapple across the six farm communities. A total of 435.22 individual nematodes were encountered across the six farm locations. The dominance index of nematode genera across the six farm locations was 0.58 , Simpson index value of 0.42 was obtained, 0.86 for Shannon Weiner index and Evenness index of 0.39 (Figure 4). Table 4 provides information on the population of plantparasitic nematodes associated with pineapple across the six farm locations of the two Local Government Areas. Aluu farm location had the highest population of Helicotylenchus species (120) which was not significantly higher than the populations obtained at Rumuekini (50) and Omagwa (40) (Table 4). The results obtained in Table 4 further shows that the highest population of Pratylenchus species (1300) was obtained at Aluu pineapple farm communities, but this was not significantly higher than similar populations at Omagwa (400) and Rumuekini (300). Rumuekini had the highest population of Paratylenchus species among the six farm communities, but no significant difference exists in their populations. Omagwa recorded the population of 20 for Meloidogyne, Rumuekini a population of 80 for Scutellonema and 30 nematode individuals for Tylenchulus in Alakahia. Aluu pineapple farms had the highest mean population of plant-parasitic nematodes (1530) which was not significantly higher than mean nematode pest population of 630 obtained at the Rumuekini farm community (Table 4). The outcome of this study showed that six nematode pest genera were found in the two Local Government Areas visited. The presence of these diverse nematode genera from the soil and root samples in all the farms visited shows that pineapple is probably a good host to plant-parasitic nematodes (PPNs) (Hassan et al., 2006; Daramola et al., 2013).

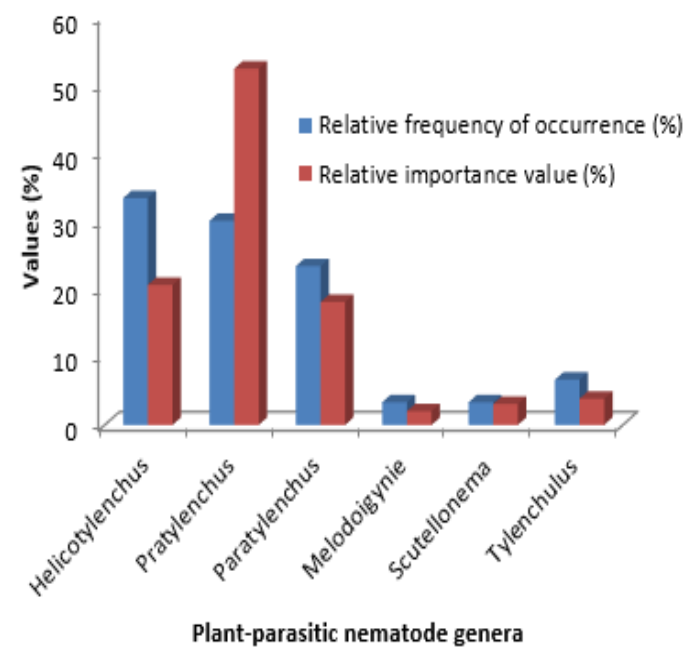

Fig 3: Occurrence and importance values of plant-parasitic nematodes associated with pineapple across six farm communities in Ikwerre and Obio-Akpor Local Government Areas, Rivers State

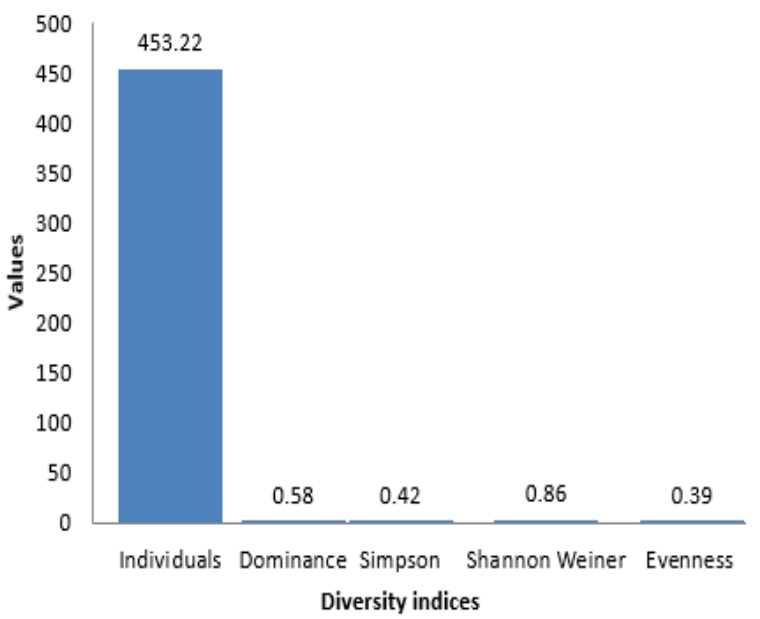

Fig 4: Diversity indices of plant-parasitic nematodes associated with pineapple across six farm communities in both Obio-Akpor and Ikwerre Local Government Areas 
Table 4: Population of plant-parasitic nematodes of pineapple across the six farm communities of Obio-Akpor and Ikwerre Local Government Areas, Rivers State

\begin{tabular}{|c|c|c|c|c|c|c|c|}
\hline \multicolumn{8}{|c|}{ Plant-parasitic nematode genera } \\
\hline $\begin{array}{l}\text { Local } \\
\text { Government } \\
\text { Areas/Farm } \\
\text { community }\end{array}$ & Helicotylenchus & Pratylenchus & Paratylenchus & Meloidogyne & Scutellonema & Tylenchulus & $\begin{array}{l}\text { Total } \\
\text { plant } \\
\text { parasitic } \\
\text { nematodes }\end{array}$ \\
\hline Aluu & 120 & 1300 & 110 & 0 & 0 & 0 & 1530 \\
\hline Omagwa & 40 & 400 & 50 & 20 & 0 & 0 & 510 \\
\hline Igwuruta & 10 & 100 & 0 & 0 & 0 & 0 & 110 \\
\hline Alakahia & 0 & 0 & 0 & 0 & 0 & 30 & 30 \\
\hline Choba & 0 & 0 & 0 & 0 & 0 & 0 & 0 \\
\hline Rumuekini & 50 & 300 & 200 & 0 & 80 & 0 & 630 \\
\hline $\operatorname{LSD}(\mathrm{P} \leq 0.05)$ & 76.29 & 729.7 & 245.2 & 23.8 & 95.3 & 23.8 & 849.8 \\
\hline
\end{tabular}

The results of this study demonstrated that Pratylenchus species is a very common plant-parasitic nematode associated with pineapple in Obio-Akpor and Ikwerre Local Government Areas. The results of this study are in conformity with outcome of the study by Daramola et al. (2013) on pineapple in Delta, Cross River and Imo States where Pratylenchus, Helicotylenchus and also Scutellonema were reported as major nematode pests on pineapple. Pratylenchus spp. has been reported as a major nematode pest of economic importance of pineapple in Malaysia and has been recorded in exceedingly high numbers in pineapple fields in Hawaii (Hassan et al., 2006). This study revealed the more occurrences of Pratylenchus in pineapple compared to other nematodes species surveyed and this is in alignment with the study carried out by Daramola et al. (2013). Other important nematode pest genera, Helicotylenchus, Scutellonema and Paratylenchus identified in association with pineapple in this study have been reported also by other workers (Stirling, 1993; Costa et al., 1998; Sipes et al., 2005). These nematode pest genera have been implicated in poor yield and reduction in sucker production of pineapple in Nigeria (Babatola, 1985). Meloidogyne species though not in significant population on pineapple in this study still enjoys the polyphagus and endoparasitic feeding nature to ensure its survival viz-a-viz fast rate of reproduction and this probably account for their presence on most crops including pineapple (Manzanilla-Lopez et al., 2004). Plant-parasitic nematodes in pineapple fields contribute to low pineapple production and they are economically important (Ko and Schmitt, 1993; Asopa, 2003). The widespread distribution of these plant-parasitic nematodes that have been known to cause plant debility and poor yields in Nigeria is a matter of concern and could be a factor in the low yield of pineapple recorded in the country (Asopa, 2003). Factors responsible for the temporal and spatial distribution of plant-parasitic nematodes in agricultural soils have been well-documented (Sipes et al., 2005). Some of these factors could be linked directly to the biology and life cycle of the nematodes, plant-host response, the environmental influences, farm history as well as the cultural practices embarked upon by farmers (Nicol, 2002; Sipes et al., 2005). All these could have contributed significantly to the distribution of plant-parasitic nematodes in pineapple fields surveyed. Of great concern also, is the fact that soil factors that promote good growth of pineapple seem to also favour rapid multiplication of nematodes. The nature and symptoms of damage caused by these nematodes make their damaging potentials to be underestimated and often mistaken for those caused by other plant pathogens such as fungi and bacteria. In most cases, farmers are not aware or adequately informed and equipped to combat this menace to crops. Besides, the results discussed here have identified key nematodes that are of economic importance in pineapple and the presence of Meloidogyne species in low population density might be an indication of poor host status of pineapple to this nematode pest. It is possible that the farming practices alongside the pineapple varieties being cultivated in this studied LGAs may have significantly influenced the presence and distribution of nematode pest populations.

Conclusion: This study revealed that pineapple is a host to economically important plant-parasitic nematodes such as Pratylenchus, Helicotylenchus and Paratylenchus in Obio-Akpor and Ikwerre Local Government Areas. Nematode pests found in these LGAs are Meloidogyne spp., Helicotylenchus spp, Pratylenchus spp., Paratylenchus mini and Scutellonema spp. Pratylenchus spp. is the most important nematode pest genus associated with pineapple and could be a major limiting factor in pineapple production in the two LGAs studied.

\section{REFERENCES}

Asopa, VN (2003). Competitiveness in Pineapple Canning Industry Hawaii International Conference on Business. June 18-21. Honolulu, Hawaii USA. Pp: 1-3.

Babatola, JO (1985). Diseases and Pests of fruits and their control in Nigeria: In proceedings of the national workshop on fruit production in Nigeria held at Federal Agriculture Coordinating Unit (FACU), Ibadan, pp. 120-131.

Bell, M (2004). Plant parasitic nematodes: Lucid key to 30 genera of plant-parasitic nematodes: retrieved on 13th September, 2011 from http://www.lucicentral.com/keys/nematodes. 
Caswell, EP; Sarah, JL; Apt, W (1990). Nematode parasite of Pineapple. In 'Plant Parasitic Nematodes in Subtropical and Tropical Agriculture', (Eds M. Luc, R.A. Sikora and J. Bridged) pp: 519-537 CAB International; Wallingford, U.K.

Caveness, FE (1965). End of tour progress report on the nematology project. Ministry of Agriculture and Natural Resources Western Region, Nigeria and the United States of America Agency for International Development. USAID/NIGERIA pp: 47.

Costa, DC; Sanches, NF; Santos, JM (1998). Levantamento de fitonematóides associados ao abacaxizeiro. Rev. Brasil. de Fruti. 20, 392-396.

Daramola, FY; Afolami, SO; Idowu, AA; Nwaguma, EA (2013) Studies on the occurrence and distribution of plant-parasitic nematodes in some pineapple-producing states in Nigeria. As. J. Crop Sci. 5(2): 190-199.

de Carvalho, TN (2020). The natural frontiers of a global empire: The pineapple-Ananas

comosus-In Portuguese Sources of the 16th Century. $\begin{array}{llll}\text { Humanities } & 2020 \quad \text { (9) } & 89 ; & 1-22\end{array}$ doi:10.3390/h9030089 retrieved online on $18^{\text {th }}$ February $2021 \quad$ from www.mdpi.com/journal/humanities

Dropkin, VH; Smith, WL; Myers, RF (1960). Recovery of nematodes from infected roots by maceration. Nematol. 5: 285-288.

FAOSTAT. (2012). Food and Agriculture Organization of the United Nations, Rome. online database. 2012. http://faostat.fao.org/(accessed 28.03.19).

FAOSTAT. (2021): Pineapple production statistic. Retrieved online on 19th March, 2021 from http://www.fao.org/faostat/en/\#rankings/countrie s by commodity

Hammer, O; Harper, DAT; Ryan, PD (2001). PAST: Paleontological statistic software package for education and data analysis. Paleontol. Electron. 4(1): $9 \mathrm{pp}$

Hassan, NM; Ismail, AB; Zulkifli, M (2006). Nematode infestation on commercial pineapple cultivation on infested Peatland. Symposium and Workshop on Tropical Peatland. Horticultural Research Center, MARDI. Malaysia. pp: 1-42.

Kent, M; Coker, P (1996). Vegetation description and analysis. A practical approach. John Wiley and Sons, NY, pp 363
Ko, MP; Schmitt, DP (1993). Pineapple inter-cycle cover crops to reduce plantparasitic nematode populations. Act. Horti.334: 373-382.

Kormelinck, AG; Janssen; I (2012). Business case Pineapple West-Kenya-Wageningen UR Centre for Development Innovation, pp 1-15.

Mark, AA (2010). The impact of large-scale pineapple companies on rural livelihoods in the Akuapim South Municipality of Ghana. Thesis submitted in partial fulfillment of the requirements for the Degree of Master of Philosophy in Culture, Environment and Sustainability. Center for Development and the Environment, University of Oslo, Blindern, Norway, 13 pp

Manzanilla-Lopez, RH; Kenneth, E; Bridge, J (2004). Plant diseases caused by nematodes. In: Chen Z.X., Chen S.Y., Dickson D.W., (Eds.). Nematology: advances and perspectives. Nematode management and utilization. Wallingford, UK, CAB International, pp. 637716.

Montinola, LR (1991). Pina (First edition). Manila, Philippines: Amon Foundation. 232 pp ISBN-10: 9718551050

Morton, J (1987). Pineapple. p. 18-28. In: Fruits of warm climates. Julia F. Morton, Miami, FL.

Nicol, JM (2002). Important nematode pests. In: Curtis, B.C., Rajaram, S., Gomez, M. (eds), Breadwheat improvement and production. FAO Plant Production and Protection Series, pp: 567

Norton, D (1978). Ecology of Plant Parasitic Nematodes. New York: John Wiley and Sons.

Ndungu, S (2014). A report on conventional pineapple production in Kenya. Prepared for Swedish Society for Nature Conservation (SSNC), Sweden.

http://www.naturskyddsforeningen.se/sites/defau lt/files/conventional_pineaple_production_Kenya .pdf. (accessed 03.04.19).

SAS. (2007). Statistical Analysis System User's Guide. SAS Institute Inc. Carry N.C. USA.

Shukla, RS; Chandel, PS (2014). A textbook of plant ecology including ethnobotany and soil science. S. Chand and Company Limited. India 512 pp

Sipes, BS (2000). Crop profile for pineapple in Hawaii. NSF center for Pest management. North Carolina State University. Society of Nematologists, Dundere, UK. Pp: 219-233. 
Sipes, B; Caswell-Chen, E; Sarah J; Apt, W (2005). Nematode parasites of pineapple. In: Luc, M., Sikora, R., and Bridge, J. (Eds.). Plant parasitic nematodes in Subtropical and Tropical agriculture. Egham, UK, CABI Publishing, pp. $709-731$.

Stirling, GR (1993). Nematodes. In: Broadley, R. H., Wassman, R.C. and Sinclair, E. (Eds.), pineapple: Pests and disorders. Brisbane, Queensland Department of Primary Industries, pp. 21-29
Ucheagwu, AC (1985). Pineapple production in Nigeria. Processing's of the National Food Production Workshops, (FP85), FACU, pp: 71-76

United States Department of Agriculture (2003): Fruit and tree nuts outlook. Bigger citrus Crop Forecast for 2003/04, http://usda01.library.cornell.edu/usda/ers/FTS11-21-2003. (Accessed 28.03.19).

Whitehead, AG; Hemming, JR (1965). A comparison of some quantitative methods of attracting small vermiform nematodes from soil. Ann. Appl. Bio. $35: 35-38$. 